Yu. A. Nitsuk, Yu. F. Vaksman, I. V. Tepliakova, A. A. Rimashevskiy

\author{
I. I. Mechnikov Odesa National University \\ e-mail:nitsuk@onu.edu.ua
}

\title{
SYNTHESIS AND LUMINESCENCE PROPERTIES OF ZnSe:Al NANOPARTICLES
}

\begin{abstract}
Colloidal nanocrystals of $\mathrm{ZnSe}$ :Al were synthesized in organic polymer matrices. The optical absorption and longwavelength luminescence were studied, the average sizes of nanoparticles were determined, the efficiency of the transition from bulk crystals to nanocrystals was shown, and the types of optical transitions were determined.
\end{abstract}

\section{Introduction}

Semiconductor colloidal nanocrystals of the $\mathrm{A}_{2} \mathrm{~B}_{6}$ group are promising materials for biomedical marking and visualization. The most widely represented in the studies are $\mathrm{CdS}$ and CdSe nanocrystals [1,2], which have tunable, wide and intense emission bands. However, many results show that any leakage of cadmium from nanocrystals will be toxic and fatal to biological systems. In connection with this, the synthesis of nanomaterials, not cadmium entities, is topical. Such materials include zinc chalcogenides, and zinc selenide in particular.

Being a wide-band semiconductor, $\mathrm{ZnSe}$ is ideally suited for the creation on its basis of optoelectronics devices and biomedical imaging. Doping $\mathrm{ZnSe}$ allows the realization of luminescent radiation in the visible and near infrared wavelengths. At present, $\mathrm{ZnSe}$ nanocrystals doped with transition elements such as $\mathrm{Cu}, \mathrm{Mn}, \mathrm{Co}$ have been successfully synthesized [3] At the same time, there is no information on the preparation of zinc selenide nanoparticles doped with Group III donor elements (Al, Ga, In). Investigations of the photoluminescence of bulk $\mathrm{ZnSe}$ : Al crystals showed that in zinc selenide an Al impurity is the best activator in the visible range [4]. So the preparation and investigation of the luminescent properties of ZnSe: Al nanocrystals is relevant.

The purpose of this work is the development of an ecological approach to the synthesis of $\mathrm{ZnSe}$ :Al nanocrystals, the study of their luminescent properties and the establishment of natural emission transitions in these nanocrystals.

\section{Experimental}

The study used commercial reagents Beijing Reagent Company. $\mathrm{ZnCl}_{2}$ was the source of zinc ions. The source of $\mathrm{Se}^{2-}$ ions was sodium selenosulfate $\mathrm{Na}_{2} \mathrm{SeSO}_{3}$, which was prepared with an aqueous $\mathrm{Na}_{2} \mathrm{SO}_{3}$ solution and powdered $\mathrm{Se}(99 \%)$. Polyvinyl alcohol, gelatin or lactose was used as the growth stabilizer of nanoparticles. The doping with $\mathrm{Al}$ ions was carried out by the addition of $\mathrm{Al}_{2} \mathrm{Cl}_{3}$. The resulting colloidal solution containing $\mathrm{ZnSe}$ and $\mathrm{ZnSe}: \mathrm{Al}$ nanoparticles was deposited on quartz substrates, then the solvent evaporated, forming membranes for measuring optical absorption and photoluminescence.

The optical absorption and photoluminescence spectra were recorded with an MDR-6 monochromator with a 2400 grove $\mathrm{mm}^{-1}$ diffraction gratings in the ultraviolet and 1200 grove $\cdot \mathrm{mm}^{-1}$ in the visible range.

\section{Investigation of the optical absorption}

The optical density spectra of $\mathrm{ZnSe}$ and ZnSe:Al nanocrystals were studied. It is established that in all the samples studied the absorption edge is shifted to the region of high energies in comparison with the absorption edge of single crystals of $\mathrm{ZnSe}$, which indicates the presence of quantum size effects in the samples. The influence of the ratio of the concentrations of zinc and selenium sources on the position of the absorption edge was established. The maximum displacement was observed at a ratio of $\mathrm{ZnCl}_{2}$ to $\mathrm{Na}_{2} \mathrm{SeSO}_{3}$ of $10: 1$. 


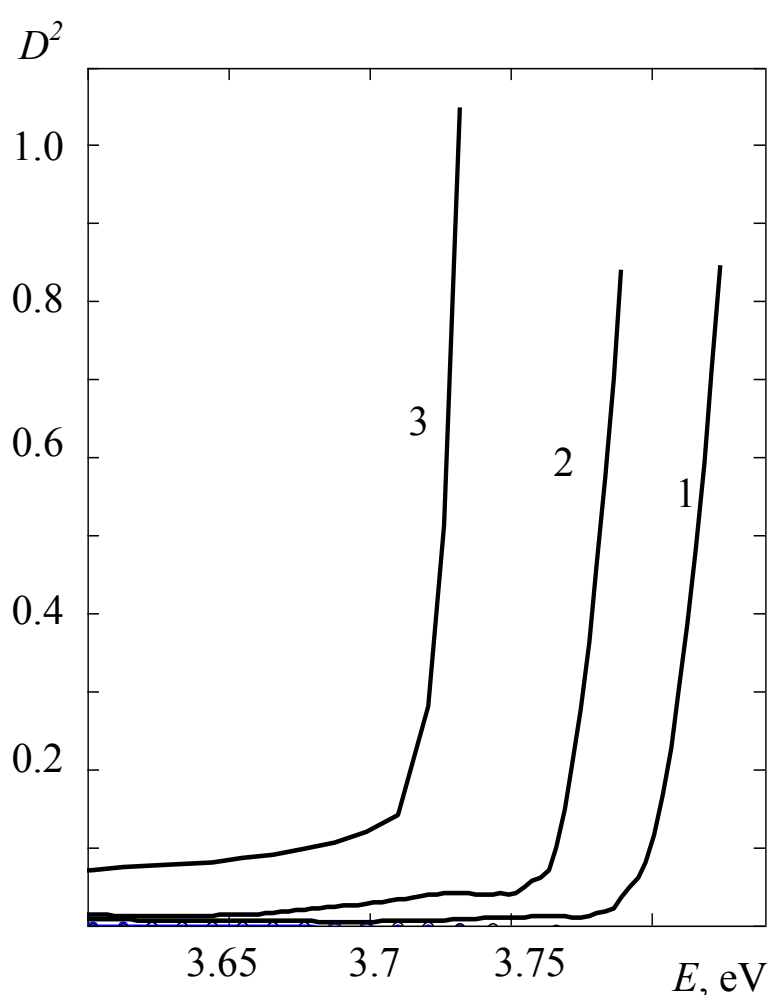

The mean radius of the $\mathrm{ZnSe}, \mathrm{ZnSe}: \mathrm{Al}$ particles was estimated from the change in the band gap $\left(\Delta E_{g}\right)$ relative to the bulk crystal, using the effective-mass approximation using the equation [5]

$$
R=\frac{h}{\sqrt{8 \Delta E_{g}}} .
$$

There $h$ is the Planck constant; $\mu=\left(\left(m_{e^{*}}\right)^{-1}+\right.$ $\left.\left(m_{h^{*}}\right)^{-1}\right)^{-1}$, where $m_{e}^{*}=0.17 m_{e}, m_{h}^{*}=0.6 m_{e}$ are, respectively, the effective masses of the electron and hole in zinc selenide, $m_{e}$ is the mass of the free electron; $\Delta E_{g}$ is the difference between the width of the band gap in the nanoparticle and the bulk crystal of $\mathrm{ZnSe}(2.68 \mathrm{eV})$. The results of calculations showed that the minimum $\mathrm{ZnSe}$ nanoparticles size $(3.5 \mathrm{~nm})$ is reached just at the ratio of $\mathrm{ZnCl}_{2}$ to $\mathrm{Na}_{2} \mathrm{SeSO}_{3}$ 10: 1 (Fig. 1, curve 1).

Doping of $\mathrm{ZnSe}$ nanocrystals with aluminum leads to a shift in the absorption edge to the region of lower energies. The magnitude of the displacement increased with increasing concentration of the aluminum source (Fig. 1, curves 2,3). A similar dependence of the width of the forbidden band on the concentration of the dopant was observed earlier in bulk ZnSe crystals containing the donor impurity In, the impurity ions of the transition el- ements, and was explained by the presence of an impurity Coulomb interaction [6]. Using relation

$$
\Delta E_{g}=2 \cdot 10^{5}\left(\frac{3}{\pi}\right)^{1 / 3} \frac{e N^{1 / 3}}{4 \pi \varepsilon_{0} \varepsilon_{s}}
$$

where: $e$ - electron charge, $N$ - concentration of impurities in $\mathrm{cm}^{-3}, \varepsilon_{\mathrm{s}}=8.66$ is zinc selenide static dielectric constant, the concentration of aluminum impurity in the investigated nanocrystals is determined. $5 \%$ solution of $\mathrm{Al}_{2} \mathrm{Cl}_{3}$ corresponds to the concentration of aluminum in nanocrystals of $10^{18} \mathrm{~cm}^{-3}$, and $10 \%$ solution of $\mathrm{Al}_{2} \mathrm{Cl}_{3}$ is a concentration of $10^{19} \mathrm{~cm}^{-3}$.

\section{Investigation of long-wavelength photolu- minescence}

Investigation of $\mathrm{ZnSe}$ nanocrystals photoluminescence spectra is showed the presence of broad photoluminescence bands localized in the 550$850 \mathrm{~nm}$ region. The change in the temperature of nanocrystals from 300 to $430 \mathrm{~K}$ did not cause a shift in the spectra studied. The position of the spectra remained unchanged even with a change in the width of the forbidden band of nanocrystals. The presence of a number of bend and a large $(\sim 150 \mathrm{~nm})$ half-width of the bands indicate their non-elementary nature. The decomposition into elementary Gaussian components in the OriginPro 7 program revealed a series of elementary emission lines localized at 580, 600, 630, 680, 700, 750 and $800 \mathrm{~nm}$ (Fig. 2, a). The identical elementary emission lines were observed earlier in bulk ZnSe single crystals (Fig. 2, b) [4].

Emission at a wavelength of $580 \mathrm{~nm}$ appears due to associative native defects $\left(\mathrm{V}_{\mathrm{Zn}} \mathrm{V}_{\mathrm{Se}}\right)^{-}$. The emission line at a wavelength of $600 \mathrm{~nm}$ appears due to associative defects $\left(\mathrm{V}_{\mathrm{Zn}} \mathrm{D}_{\mathrm{Se}}\right)^{-}$where the donor is either $\mathrm{V}_{\mathrm{Se}}$ or an uncontrolled donor impurity, an IIV group element, for example, $\mathrm{Cl}, \mathrm{Br}$, I. The other emission lines were associated with defects $\left(\mathrm{V}_{\mathrm{Zn}} \mathrm{D}_{\mathrm{Zn}}\right)$ - with different distances between donors and acceptors. Here the donor, according to [4], is the uncontrolled impurities A1, In, Ga.

Doping with aluminum during the growth of nanocrystals leads to an increase in the emission intensity in the 500-1000 nm region. Further increase of the emission intensity with increasing 


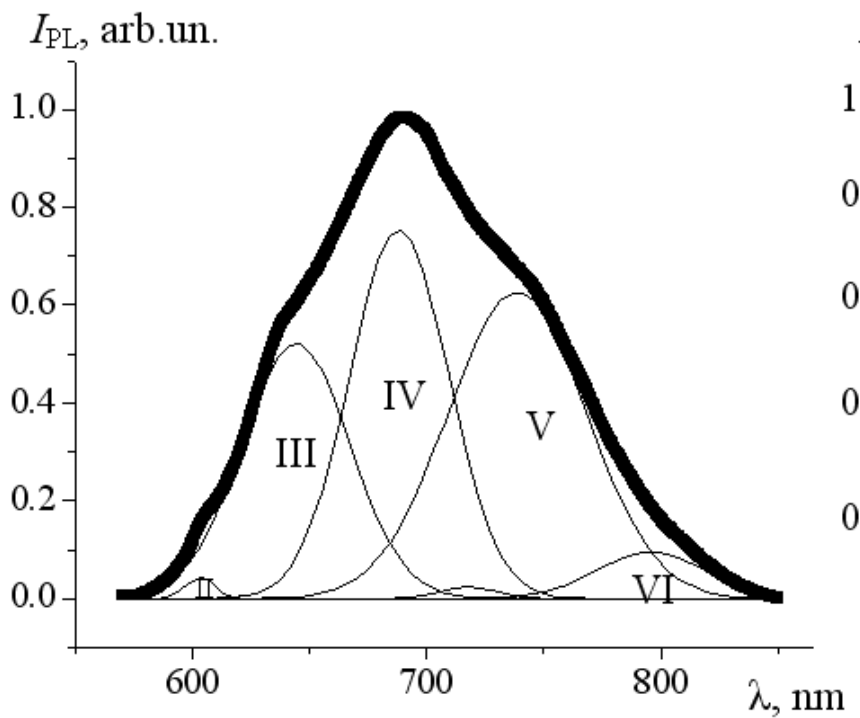

a)
$I_{\mathrm{PL}}$, arb.un.

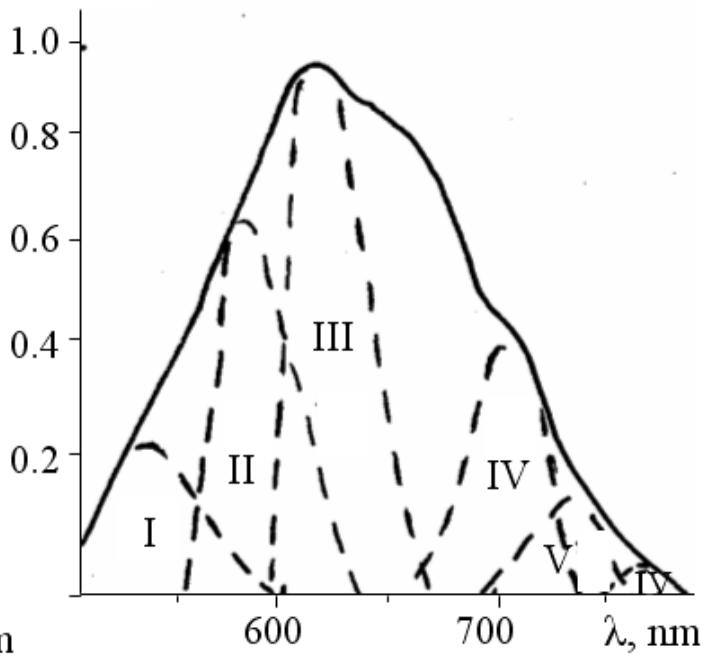

b)

Fig 2. Photoluminescence spectra of (1) ZnSe nanocrystals and (b) ZnSe bulk crystals [4].

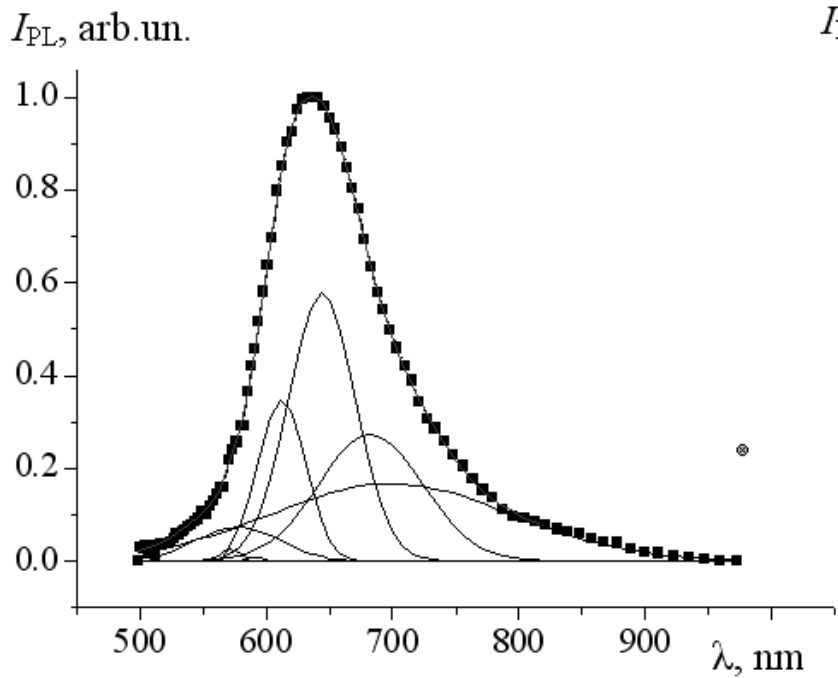

a)

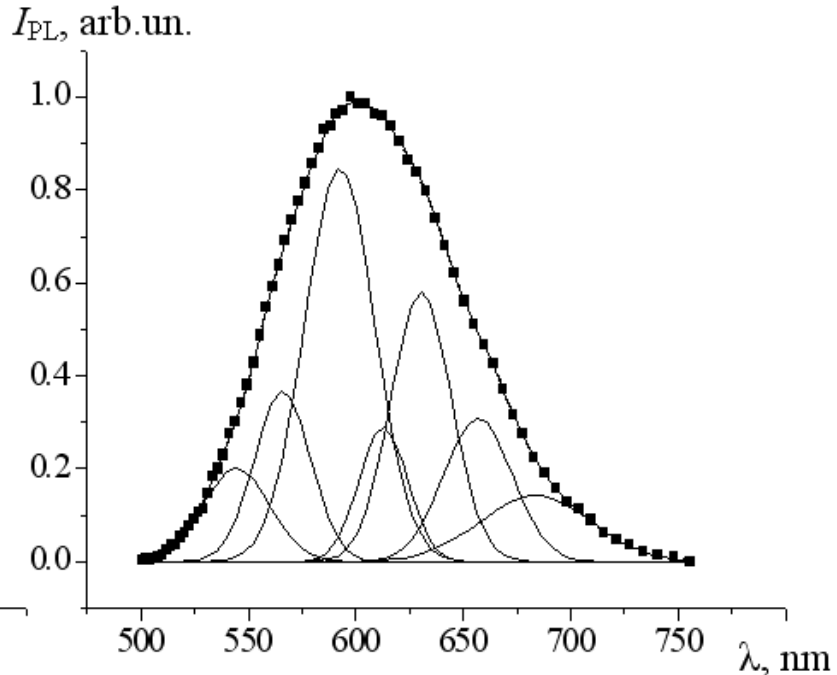

b)

Fig 3. Photoluminescence spectra of (a) ZnSe:Al nanocrystals and (b) ZnSe:Al bulk crystals.

$\mathrm{Al}_{2} \mathrm{Cl}_{3}$ concentration is explained by an increase of the donor impurity concentration in investigated nanocrystals.

In the emission spectra of $\mathrm{ZnSe}$ :Al nanocrystals, elementary emission lines are emitted at 580, $600,630,680$, and $700 \mathrm{~nm}$. The same emission lines were detected in bulk crystals of $\mathrm{ZnSe}: \mathrm{Al}$ (Fig. 3, b).

It is established that a change of $\mathrm{Al}_{2} \mathrm{Cl}_{3}$ concentration, the choice of the stabilizing matrix type does not lead to a shift of the elementary and integral emission lines to the short-wave or long-wave region. The change in technological conditions leads to a change in the intensity of the elementary emission lines, which is explained by the redistribution of the concentration of native and impurity defects that make up the associative centers. The shift of the emission integrated maximum to the smaller wavelengths region with increasing $\mathrm{Al}_{2} \mathrm{Cl}_{3}$ concentration from 2 to $10 \%$ can be explained by increasing in the intensity of the elementary emission line at $600 \mathrm{~nm}$ due to associative defects $\left(\mathrm{V}_{\mathrm{Zn}} \mathrm{Cl}_{\mathrm{Se}}\right)$. 


\section{Conclusions}

ZnSe and ZnSe: $\mathrm{Al}$ nanoparticles up to $3.5 \mathrm{~nm}$ in diameter were successfully synthesized using the "green" synthesis method and organic stabilizing agents. It is shown that $\mathrm{ZnSe}$ :Al nanoparticles possess effective long-wave emission and can be used as fluorescent labels. The nature of the radiative transitions in $\mathrm{ZnSe}$ and $\mathrm{ZnSe}: \mathrm{Al}$ nanocrystals is established. It has been experimentally confirmed that when the transition from bulk crystals to nanocrystals does not occur, the emission lines shift toward donor-acceptor pairs.

\section{References}

1. X. Peng, M. C. Schlamp, A. V. Kadavanich, and A. P. Alivisatos, "Epitaxial growth of highly luminescent $\mathrm{CdSe} /$ $\mathrm{CdS}$ core/shell nanocrystals with photostability and electronic accessibility," Journal of the American Chemical Society, vol. 119 , no. 30, pp. 7019-7029, 1997.

2. B. O. Dabbousi, J. Rodriguez-Viejo, F. V. Mikulec et al., "(CdSe $) \mathrm{ZnS}$ core- shell quantum dots: synthesis and characterization of a size series of highly luminescent nanocrystallites," Journal of Physical Chemistry B, vol. 101, no. 46, pp. 9463-9475, 1997.

3. D Han, C. Song X. Li. Synthesis and Fluorescence Property of Mn-Doped ZnSe Nanowires // J. Nanomaterials. 2010. - P.1-4.

4. Serdyuk V.V., Korneva N.N., Vaksman Yu.F. Studies of Long-Wave Luminescence of Zinc Selenide Monocrystals // Phys. Stat. Sol.(a). - 1905. - V.91. P. 173-183.

5. Гусев А.И., Ремпель А.А. Нанокристаллические материалы. М:Физматлит. - 2000. -С 224.

6. Vaksman Yu.F., Nitsuk Yu.A., Purtov Yu.N. and Shapkin P.V. Native and Impurity Defects in ZnSe:In Single Crystals Prepared by Free Growth// Semiconductors. - 2001. - V. 35, № 8 . - P. 920-926.

This article has been received in May 2017

UDC 621.315 .592

Yu. A. Nitsuk, Yu. F. Vaksman, I. V. Tepliakova, A. A. Rimashevskiy

\section{SYNTHESIS AND LUMINESCENCE PROPERTIES OF ZnSe:Al NANOPARTICLES}

\section{Summary}

Colloidal nanocrystals of $\mathrm{ZnSe}: \mathrm{Al}$ were synthesized in organic polymer matrices. The optical absorption and long-wavelength luminescence were studied, the average sizes of nanoparticles were determined, the efficiency of the transition from bulk crystals to nanocrystals was shown, and the types of optical transitions were determined.

Key words: ZnSe, ZnSe:Al, nanoparticles, colloidal synthesis, optical properties, luminescence, biomedical markers. 
Ю. А. Ніиук, Ю. Ф. Ваксман, І. В. Теплякова, О. А. Рімашевський

\title{
СИНТЕЗ ТА ЛЮМІНЕСЦЕНТНІ ВЛАСТИВОСТІ НАНОКРИСТАЛІВ ZnSe:Al
}

\begin{abstract}
Анотація
Колоїдні наночастинки ZnSe:Al були синтезовані в органічній полімерній матриці. Були досліджені оптичне поглинання та довгохвильова фотолюмінесценція. За зсувом ширини забороненої зони визначений середній розмір наночастинок. Визначена природа випромінювальних переходів.

Ключові слова: ZnSe, ZnSe:Al, наночастинки, колоїдний синтез, оптичні властивості, люмінесценція, біомаркери.
\end{abstract}

УДК 621.315 .592

Ю. А. Нииук, Ю. Ф. Ваксман, И. В. Теплякова, А. А. Римашевский

\section{СИНТЕЗ И ЛЮМИНЕСЦЕНТНЫЕ СВОЙСТВА НАНОКРИСТАЛЛОВ ZnSe:Al}

\section{Аннотация}

Коллоидные наночастицы ZnSe:Al были синтезированы в органиче6ской полимерной матрице. Были исследованы оптическое поглощение идлинноволновая люминесценция. По смещению ширины запрещенной зоны определялся средний раз мер наночастиц. Определена природа излучательных переходов.

Ключевые слова: ZnSe, ZnSe:Al, наночастицы, коллоидный синтез, оптические свойства, люминесценция, биомаркеры. 